\title{
Murine streptozotocin diabetes: influences of the major histocompatibility complex, genetic background and blood transfusion
}

\author{
${ }^{1} \mathrm{C}$. Weber, ${ }^{2}$ B.Pernis, ${ }^{1}$ W. Ting, ${ }^{1} \mathrm{~K}$. Rosenkrantz and ${ }^{1} \mathrm{~K}$. Reemtsma \\ Departments of ${ }^{1}$ Surgery, ${ }^{2}$ Microbiology and Medicine, Columbia University, New York, USA
}

\begin{abstract}
Summary. Major histocompatibility complex-linked immune response genes are thought to influence susceptibility to induction of both human insulin-dependent diabetes and murine streptozotocin-induced diabetes. To clarify this relationship, we administered streptozotocin intravenously in two doses (120 and $240 \mathrm{mg} / \mathrm{kg}$ body weight) on days 0 and 14 , and monitored blood glucose until day 100 in young adult male mice of differing background genome and/or $\mathrm{H}-2$ complex. In addition, we examined the effect of allogeneic whole blood transfusion on subsequent susceptibility to diabetes. B10 recombinant mice possessing the $k$ allele at the centromeric $\mathrm{H}$ 2-K and I-A loci were most susceptible to diabetes induction.
\end{abstract}

Variation in susceptibility of different inbred strains with the same major histocompatibility complex genotype suggested a rôle for non-major histocompatibility complex genes. Blood transfusion delayed the onset, but did not significantly reduce the incidence of, delayed hyperglycaemia. We conclude that, in this murine model, multiple genes within and outside the major histocompatibility complex influence multiple-dose streptozotocin-diabetes susceptibility, and that prior blood transfusion may modulate diabetes induction.

Key words: Mouse, streptozotocin, MHC, blood transfusion.
Multiple-dose streptozotocin (STZ) diabetes in mice is accompanied by lymphocytic infiltration of islets, hyperglycaemia and hypoinsulinaemia, similar to human Type 1 (insulin-dependent) diabetes [1]. Major histocompatibility complex (MHC)-linked immune response genes are thought to influence susceptibility to induction of human Type 1 diabetes $[2,3]$.

Several studies have suggested that susceptibility of mice to multiple-dose STZ treatment is influenced by genes within the MHC [3-7]. Kiesel et al. [7], using five daily intraperitoneal injections of $50 \mathrm{mg} / \mathrm{kg}$ body weight of STZ, found significant differences in the development of diabetes in B10 recombinant mice, and suggested that genes coding for susceptibility may be located in the centromeric (left) region of the $\mathrm{H}-2$ complex.

We have obtained similar data with inbred, as well as recombinant B10 mice, using a regimen of two doses of STZ (120 and $240 \mathrm{mg} / \mathrm{kg}$ body weight) administered intravenously, 2 weeks apart. Furthermore, we have found that prior blood transfusion delays the onset of hyperglycaemia.

\section{Methods}

STZ (2-deoxymethyl-nitrosourea-glucopyranose) was a gift from the Upjohn, Kalamazoo, Michigan, USA. Mice were obtained from Jackson Laboratories, Bar Harbor, Maine, USA, with the exception of $\mathrm{Balb} / \mathrm{k}$ mice which were a gift from Dr. D. Sachs (National Institutes of Health) and B10.AQR mice, a gift from Dr. C. David (Mayo Clinic,
Rochester, Minnesota, USA). All mice used were young adult males, aged 6-12 weeks. Animals were housed in groups of five in metabolic cages and were fed standard laboratory chow and water ad libitum. The numbers of mice studied for each strain are listed in Table 1.

STZ was given in two intravenous doses, spaced 14 days apart $(120$ and $240 \mathrm{mg} / \mathrm{kg}$ ), in citrate buffered saline ( $\mathrm{pH} 4.5$ ) via the femoral vein, under light ether anaesthesia. Data collected from each mouse included random blood glucose determinations [8] before and after treatment, and subsequently thrice weekly for 100 days. For the purpose of this study, diabetes was defined as blood glucose $>$ $14 \mathrm{mmol} / \mathrm{l}$ for more than 10 days.

Donors of blood were B10.D2, B10.A(2R) and B10.A male mice which had been exposed to a double dose of intravenous STZ 7-10 days prior to exsanguination, and which were mildly hyperglycaemic (blood glucose 6.7-11.1 mmol/1). Recipient B10.BR mice received heparinized whole blood $(0.2 \mathrm{ml})$ transfusions via the femoral vein, under light ether anaesthesia, on two or three occasions weekly, followed by two intravenous doses of STZ commenced 3-7 days after the last transfusion. Control animals received no transfusion but similar STZ treatments.

\section{Statistical analyses}

Chi square analysis was used to assess significance of differences in incidence of diabetes between concurrently STZ-treated mice of the several strains listed in Table 1 . All comparisons were made with the highly susceptible B10.BR strain.

\section{Results}

$\mathrm{H}-2^{\mathrm{k}}$ B10.BR mice were highly susceptible to diabetes induction, whereas $\mathrm{H}-2^{\mathrm{b}} \mathrm{B} 10$ mice were highly resistant $(p<0.01$, days $50-60)$ and H-2 ${ }^{\mathrm{d}}$ B10.D2 mice were only partially susceptible $(p<0.05$, days 50-60; Fig. 1 , 
Table 1. Susceptibility of mice to diabetes following treatment with streptozotocin

H-2 complex (MHC) Number of diabetic mice $/$ total number studied

\begin{tabular}{llllllllll}
\multicolumn{1}{l}{ I-region } & & & & Day $30^{\text {b }}$ & Day 40 & Days 50-60 & Days 70-80 & Day 100 \\
\hline K A A J & E & C & S & D & & & & &
\end{tabular}

\begin{tabular}{|c|c|c|c|c|c|c|c|c|c|c|c|c|}
\hline \multicolumn{13}{|l|}{ Inbred strains } \\
\hline C3H.HEJ & $\mathrm{k}$ & $\mathrm{k}$ & $\mathrm{k}$ & $\mathrm{k}$ & $\mathbf{k}$ & k 1 & $\mathrm{k}$ & $0 / 14^{\text {cd }}$ & $7 / 14$ & $9 / 13$ & $7 / 12$ & $2 / 6$ \\
\hline $\mathrm{Balb} / \mathrm{c}$ & $\mathrm{d}$ & $\mathrm{d}$ & $\mathrm{d}$ & d & $\mathrm{d}$ & d & d & $7 / 8$ & $6 / 7$ & $2 / 3$ & $2 / 2$ & $1 / 1$ \\
\hline $\mathrm{A} / \mathrm{J}$ & $\mathrm{k}$ & $\mathrm{k}$ & $\mathrm{k}$ & $\mathrm{k}$ & $\mathrm{d}$ & d & d & $6 / 7$ & $5 / 6$ & $5 / 6$ & $4 / 5$ & $2 / 3$ \\
\hline DBA & d & $\mathrm{d}$ & $\mathrm{d}$ & $\mathrm{d}$ & $\mathrm{d}$ & d & d & $1 / 5^{\mathrm{d}}$ & $3 / 5$ & $4 / 5$ & $3 / 3$ & $2 / 2$ \\
\hline $\mathrm{C} 57 \mathrm{BL} / 6 \mathrm{~J}$ & $b$ & $\mathrm{~b}$ & $\mathrm{~b}$ & - & $\mathrm{b}$ & $\mathrm{b}$ & b & $24 / 24$ & $24 / 24$ & $16 / 16$ & $9 / 9$ & -- \\
\hline B10.D2 & $\mathrm{d}$ & $\mathrm{d}$ & $\bar{d}$ & $\mathrm{~d}$ & $\mathrm{~d}$ & d & d & $12 / 31^{d}$ & $13 / 25$ & $9 / 20^{e}$ & $5 / 5$ & $5 / 5$ \\
\hline $\mathrm{B} 10(\mathrm{C} 57 \mathrm{BL} / 10)$ & $b$ & b & $b$ & - & b & b & b & $2 / 22^{\mathrm{d}}$ & --- & $5 / 22^{d}$ & $1 / 10^{\mathrm{e}}$ & $1 / 10$ \\
\hline B10.A & $\mathrm{k}$ & $\mathrm{k}$ & $\mathrm{k}$ & $\mathrm{k}$ & $\mathrm{d}$ & $\mathrm{d}$ & d & $3 / 27^{d}$ & $4 / 10^{d}$ & $1 / 8^{d}$ & $1 / 8^{e}$ & $1 / 8$ \\
\hline $\mathrm{B} 10 . \mathrm{A}(2 \mathrm{R})$ & $\mathrm{k}$ & $\mathrm{k}$ & $\mathrm{k}$ & $\mathrm{k}$ & $\mathrm{d}$ & d 1 & b & $4 / 26^{d}$ & --- & $16 / 26$ & $10 / 12$ & $8 / 10$ \\
\hline B10.A(4R) & $\mathrm{k}$ & $\mathrm{k}$ & $b$ & - & b & b $\quad$ l & b & ---- & $8 / 12$ & $9 / 12$ & $4 / 6$ & --- \\
\hline B10.AKM & $\mathrm{k}$ & $\mathrm{k}$ & $\mathrm{k}$ & $\mathrm{k}$ & $\mathrm{k}$ & $\mathrm{k}$ & $q$ & $6 / 8$ & $6 / 8$ & $6 / 8$ & $6 / 8$ & $6 / 8$ \\
\hline B10.A Blood & & & & & & & & $3 / 6$ & $4 / 6$ & $4 / 6$ & $4 / 6$ & $1 / 4$ \\
\hline B10.A(2R) Blood & & & & & & & & $1 / 9$ & $6 / 9$ & $8 / 9$ & $6 / 7$ & $1 / 2$ \\
\hline B10.D2 Blood & & & & & & & & $4 / 8$ & $4 / 8$ & $4 / 8$ & $5 / 8$ & $3 / 7$ \\
\hline Totals & & & & & & & & $8 / 23^{\mathrm{d}}$ & $14 / 23$ & $16 / 23$ & $15 / 21$ & $5 / 13$ \\
\hline
\end{tabular}

a Stable random blood glucose $>14 \mathrm{mmol} / 1$ over more than 10 days;

b STZ given $120 \mathrm{mg} / \mathrm{kg}$ body weight intravenously on day 0 , and $240 \mathrm{mg} / \mathrm{kg}$ intravenously on day 14 ;

c C3H.HEJ animals given a third dose of STZ on day $30(300 \mathrm{mg} / \mathrm{kg}$ intravenously);

d $p<0.01, \chi^{2}$ analysis, compared to incidence of diabetes in B10.BR mice;

e $p<0.05, \chi^{2}$ analysis, compared to incidence of diabetes in B10.BR mice

Table 1). In fact, $15 \%$ of B10.BR mice became diabetic after the first dose of STZ. At the K and I-A loci, $k$ alleles conferred susceptibility, since B10.A(4R) mice were as susceptible to diabetes induction as were B10.BR mice. Susceptibility of B10.MBR and B10.AQR mice, which like B10.BR and B10.A(4R), are $k$ at the I-A locus, and the resistance of $\mathrm{B} 10 . \mathrm{A}(5 \mathrm{R})$ mice, which are $b$ at the I-A locus, suggested that the I- $\mathrm{A}^{\mathrm{k}}$ genome may promote diabetes susceptibility in B10 recombinant mice. Delay in onset of hyperglycaemia in B10.A(2R) was similar to that observed in relatively resistent B10.D2 mice. This observation, as well as resistance of B10.(A) mice, suggests that $\mathrm{I}-\mathrm{A}^{\mathrm{k}}$ susceptibility may be modulated by $[-\mathrm{E}, \mathrm{C}$ or $\mathrm{D}$ alleles.

Variation in susceptibility of different inbred strains with the same MHC genotype (i.e. C3H.HEJ, Balb/k and $\mathrm{B} 10 . \mathrm{BR}$ ) suggests that non-MHC genes also influence diabetes susceptibility in this model.

Transfusion of blood from STZ-exposed B10.D2 or B10.A(2R) donors prevented diabetes occurrence after the first intravenous dose of STZ, and delayed onset of hyperglycaemia in comparison with control animals $(p<0.01)$. Incidence of lasting diabetes following transfusion from B10.D2 and B10.A donors was similar to that of control animals (Table 1). Numbers of experimental versus control animals were too small to demon- strate postulated protection from diabetes in transfused mice.

\section{Discussion}

Our data support the hypothesis that immune response genes within the MHC modulate development of diabetes in $\mathrm{B} 10$ recombinant mice following intravenous exposure to STZ. MHC restriction of diabetes susceptibility in this model is the most persuasive evidence to date that it resembles human Type 1 diabetes.

Our method of STZ administration differs from that used in other studies. The findings confirm MHC, as well as non-MHC, influences upon susceptibility to intravenous STZ given in substantial doses spaced 2 weeks apart. Similarities between our data and those from other laboratories using different regimens suggest that the findings are generally valid.

Of particular interest is localization of STZ-diabetes susceptibility genes to the centromeric (left) side of the MHC. Our data are consistent with that of Kiesel et al. [7], namely that $k$ alleles at $\mathrm{H}-2-\mathrm{K}$ and I-A loci are associated with susceptibility to $\mathrm{STZ}$ in $\mathrm{B} 10$ recombinant mice. Sensitivity of B10.MBR and B10.AQR mice, and resistance of $B 10 . A(5 R)$ mice further localize susceptibility to the I-A region. 

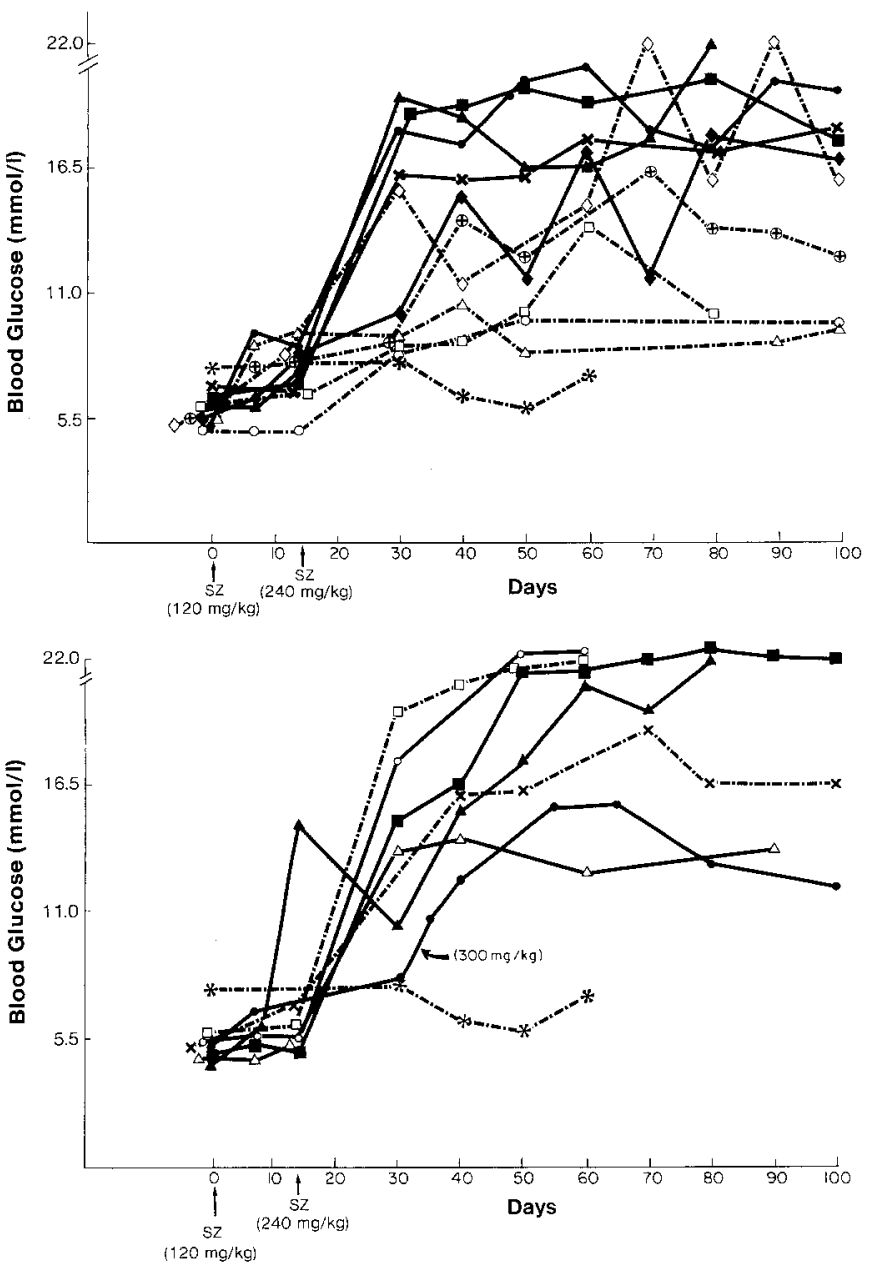

Fig. 1. Mean non-fasting blood glucose values for mice over 100 days following initiation of STZ treatment. Top panel:

-B10.BR; $\triangle \mathrm{B} 10 . \mathrm{A}(4 \mathrm{R})$; $\mathrm{B} 10 . \mathrm{MBR} ; \times \mathrm{B} 10 . \mathrm{AKM}$; B10.D2; $\diamond \mathrm{B} 10 . \mathrm{AQR} ; \quad \square \mathrm{B} 10 . \mathrm{A}(5 \mathrm{R}) ; \quad \mathrm{OB} 10(\mathrm{C} 57 \mathrm{Bl} / 10) ; \quad \triangle \mathrm{B} 10 . \mathrm{A} ;$ $\oplus \mathrm{B} 10 . \mathrm{A}(2 \mathrm{R})$; ${ }^{*}$ Normal B10.BR control mice. Lower panel: -C3H.HEJ; $\triangle \mathrm{DBA} / 6 \mathrm{~J} ; \quad$ C $3 \mathrm{H} . \mathrm{SW} ;$ OBalb $/ \mathrm{k} ; \triangle \mathrm{Balb} / \mathrm{c}$; 口C $57 \mathrm{Bl} / 6 \mathrm{~J} ; \times \mathrm{A} / \mathrm{J} ; *$ Normal B10.BR control mice

Immune response gene influences upon STZ-diabetes susceptibility correlate with similar I-A locus influences on susceptibility to murine autoimmune thyroiditis [9], myasthenia gravis [10] and experimental allergic encephalitis [11]. Modulation of I-A region influences by other loci within the MHC are apparent in our experiments, and are consistent with recent evidence in studies of genetic regulation of the immune response to hepatitis-B surface antigen [12], in which I-C sub-region genes were found to modulate I-A region susceptibility genes.

In addition to MHC influences, our studies of different inbred strains of mice with the same $\mathrm{MHC}$ phenotype suggest that non-MHC genes also influence diabetes susceptibility in this murine model. It is evident therefore, that multiple genes within and outside of the MHC influence development of diabetes following intravenous exposure to streptozotocin.

Allogeneic whole blood transfusion modulated the onset of diabetes in B10.BR mice. The mechanism of this transfusion effect is as yet unknown. Our data are similar to findings in the BB rat [13] and are consistent with the beneficial transfusion effects on human kidney transplant survival [14], which also remain largely unexplained. Transfusion effects on diabetes susceptibility will require further study.

Acknowledgements. The authors thank Ms. S. Rivera, Ms. L. Strausberg and Ms. G. LaForet for excellent technical assistance. Supported by grants from the National Institutes of Health (AM30927), The S\&A Foundation, The Kroc Foundation and the David Habif Surgical Research Fund. Dr. Weber is the recipient of RCDA No. KO4-AM00806.

\section{References}

1. Like A, Appel M, Williams R, Rossini A (1978) Streptozotocin-induced pancreatic insulitis in mice. Lab Invest 38: 470-486

2. Grodsdy G, Anderson C, Coleman D, Craighead J, Gerritsen G, Hansen C, Herberg L, Howard C, Jr., Lernmark A, Matchinsky F, Rayfield E, Riley W, Rossini A (1982) Metabolic and underlying causes of diabetes mellitus. Diabetes 31: 45-53

3. Naji A, Silvers WK, Barker CF (1983) Autoimmunity and Type I (insulin-dependent) diabetes mellitus. Transplantation 36: 355-366

4. Rossini A, Appel M, Williams M, Like A (1977) Genetic influence of the streptozotocin-induced insulitis and hyperglycemia. Diabetes 26:916 -920

5. Leiter E (1982) Multiple low-dose streptozotocin-induced hyperglycemia and insulitis in C57BL mice: Influence of inbred background, sex, and thymus. Proc Natl Acad Sci 79:630-634

6. Kromann H, Christy M, Egeberg J, Lernmark A, Nerup J (1982) Absence of H-2 genetic influence on streptozotocin-induced diabetes. Diabetologia 23: 114-118

7. Kiesel U, Falkenberg F, Kolb H (1983) Genetic control of lowdose streptozotocin-induced autoimmune diabetes in mice. J Immunol 130: 1719-1722

8. Jarrett R, Keen H, Hardwick C (1970) Instant blood sugar measurement using Dextrostix and a reflectance meter. Diabetes 19 : 724-726

9. Beisel K, David C, Giraldo A, Kong Y, Rose N (1982) Regulation of experimental autoimmune thyroiditis; mapping of susceptibility to the I-A subregion of the mouse $\mathrm{H}-2$. Immunogenetics 15 : $427-430$

10. Christadoss $P$, Lennon V, Kroc C, David C (1982) Genetic control of experimental autoimmune myasthenia gravis in mice III. Ia acetylcholine receptors. J Immunol 128: 1141-1144

11. Steinmann L, Rosenbaum J, Shiram S, McDevitt H (1981) In vivo effects of antibodies to immune response gene products prevention of experimental allergic encephalitis. Proc Natl Acad Sci USA 78: 7111-7114

12. Milich DR, Leroux-Roels GG, Louie RE, Chisari FV (1984) Genetic regulation of the immune response to hepatitis $B$ surface antigen (HBsAg); IV. Distinct $\mathrm{H}$-2-linked Ir genes control antibody responses to different $\mathrm{HBs} \mathrm{Ag}$ determinants on the same molecule and map to the I-A and I-C subregions. J Exp Med 159: 41-56

13. Rossini A, Mordes JP, Pelletier AM, Like AA (1983) Transfusions of whole blood prevent spontaneous diabetes mellitus in the $\mathrm{BB} / \mathrm{W}$ rat. Science 219:975-977

14. Terasaki PI (1984) The beneficial transfusion effect on kidney graft survival attributed to clonal deletion. Transplantation 37: 119-125

Dr. C. Weber

622 West 168 Street

New York, NY 10032

USA 